\title{
3-weekly or weekly cisplatin concurrently with radiotherapy for patients with squamous cell carcinoma of the head and neck - a multicentre, retrospective analysis
}

Seth Helfenstein ${ }^{1}$, Oliver Riesterer ${ }^{2}$, Urs R. Meier ${ }^{3}$, Alexandros Papachristofilou', Benjamin Kasenda ${ }^{4}$, Miklos Pless ${ }^{5+}$ and Sacha I. Rothschild ${ }^{1 *+}$ (D)

\begin{abstract}
Background: Concurrent chemoradiotherapy with cisplatin is standard for patients (pts) with loco-regionally advanced squamous cell carcinoma of the head and neck (LA-SCCHN) and for patients with resected SCCHN with high-risk features. The standard regimen includes 3-weekly cisplatin, but weekly regimens are often used to lower toxicity. Reaching a cumulative dose of $\geq 200 \mathrm{mg} / \mathrm{m}^{2}$ cisplatin was shown being associated with improved outcome. We herein investigated cumulative dose reached and toxicities between the 3-weekly and weekly cisplatin regimens with concurrent radiotherapy.
\end{abstract}

Methods: Multicentre, retrospective analysis of all patients undergoing combined RCT with cisplatin treated at 3 centres in Switzerland between 06/2008 and 12/2015.

Results: Three hundred fourteen pts. were included (3-weekly, $N=127$; weekly, $N=187$ ). Median cumulative cisplatin dose was $200 \mathrm{mg} / \mathrm{m}^{2}$ (IQR 150-300) for pts. treated with a 3-weekly schedule and $160 \mathrm{mg} / \mathrm{m}^{2}(120-240)$ for the weekly schedule, consequently more pts. treated with a 3-weekly schedule reached a cumulative dose $\geq 200 \mathrm{mg} / \mathrm{m}^{2}$ (75.6\% vs. $\left.47.1 \%, p<0.001\right)$. This association was also observed in multivariable analysis adjusted for age and sex (OR 3.46, 95\% confidence interval [CI], 2.1-5.7). The 3-weekly regimen led to a higher rate of acute renal toxicity ( $33.1 \%$ vs. $20.9 \%, p=0.022$ ). In the landmark analysis, we could not confirm that a cisplatin dose $\geq 200 \mathrm{mg} / \mathrm{m}^{2}$ is associated with better survival (HR 1.3, 95\% Cl 0.8-1.9).

Conclusions: Significantly more patients receive a cumulative cisplatin dose of $\geq 200 \mathrm{mg} / \mathrm{m}^{2}$, when treated with a 3 -weekly schedule compared to weekly dosing. The previously reported association between a cumulative cisplatin dose $\geq 200 \mathrm{mg} / \mathrm{m}^{2}$ and improved outcome could not be shown in our study.

Keywords: Head and neck squamous carcinoma, Chemo-radiotherapy, Treatment, Cisplatin, Dose

\section{Background}

Prognosis of patients with squamous cell carcinoma of the head and neck (SCCHN) has improved in the last decades [1-4]. However, most SCCHN patients are diagnosed with loco-regionally advanced (LA-SCCHN) stage disease. In this setting, multimodal therapy including combined

\footnotetext{
* Correspondence: sacha.rothschild@usb.ch

${ }^{+}$Miklos Pless and Sacha I. Rothschild are contributed equally.

${ }^{1}$ Department Internal Medicine, University Hospital Basel, Medical Oncology, Petersgraben 4, 4031 Basel, Switzerland

Full list of author information is available at the end of the article
}

radiochemotherapy (RCT) either as adjuvant therapy after tumor resection or as definitive curatively intended treatment approach is recommended. Several Phase III randomized trials confirmed improved loco-regional control and longer survival for high-risk patients with combined versus sequential RCT with cisplatin in the definitive [5-7] and postoperative setting [8-10]. For non-surgical cases the meta-analysis by Pignon et al. including 93 trials and more than 17'000 patients demonstrated an overall survival (OS) benefit from the addition of chemotherapy of $6.5 \%$ at five years

(c) The Author(s). 2019 Open Access This article is distributed under the terms of the Creative Commons Attribution 4.0 International License (http://creativecommons.org/licenses/by/4.0/), which permits unrestricted use, distribution, and 
compared to radiotherapy (RT) alone [11]. In a second meta-analysis, these results were confirmed and it was demonstrated that concurrent (but not sequential) RCT improved median OS by one year [12]. The standard treatment regimen consists of three cycles of cisplatin $100 \mathrm{mg} / \mathrm{m}^{2}$ given on days 1,22 and 43 of a 7 week RT course $[5,6,13]$. Due to adverse events (AEs) of this intensive regimen, chemotherapy modifications (dose reductions, delays, and omissions) are required in up to $40 \%$ of patients $[14,15]$. The main AEs due to cisplatin include renal insufficiency, electrolyte disorders, myelo- and ototoxicity $[6,8,9,16]$. Suboptimal compliance with cisplatin regimen might negatively impact patient outcome $[5,17,18]$. Therefore, alternative treatment schedules including low-dose cisplatin have been investigated [7, 19-24]. Based on these studies, weekly cisplatin administered at a dose of $30-40 \mathrm{mg} / \mathrm{m}^{2}$ is frequently used $[7,19,21,22,24]$. Regardless of the treatment regimen, it has been suggested that a cumulative dose of $200 \mathrm{mg} / \mathrm{m}^{2}$ needs to be reached for therapeutic benefit $[11,25]$. A retrospective analysis revealed inferior outcome with a cumulative cisplatin dose of $\leq 200 \mathrm{mg} / \mathrm{m}^{2}$ in HPV-negative patients. Recently, a randomized phase III non-inferiority trial suggested that a 3-weekly schedule with cisplatin 100 $\mathrm{mg} / \mathrm{m}^{2}$ results in superior loco-regional control compared to a weekly dose of $30 \mathrm{mg} / \mathrm{m}^{2}$ [23]. However, the higher dose regimen was associated with significantly more acute toxicities of grade 3 or higher. Although this is the first randomized trial, the results have to be interpreted with caution as more than $90 \%$ of patients were diagnosed with oral cavity tumors and more than $90 \%$ of patients were treated with RCT in the postoperative setting. Several other comparisons between different treatment regimens have been made mainly in retrospective [26-32] and small prospective trials [33-35] and showed contradictory findings.

The aim of this multicenter, retrospective analysis was to compare outcome, cumulative cisplatin dose and acute treatment toxicity in patients undergoing RCT for SCCHN receiving 3-weekly or weekly cisplatin concurrently with intensity-modulated radiotherapy (IMRT).

\section{Methods}

\section{Study population}

In this multicentre, retrospective, non-interventional study, we included 314 patients treated at three hospitals in Switzerland (University Hospital Basel (USB), University Hospital Zürich (USZ), Cantonal Hospital Winterthur (KSW)) between June 2008 and December 2015 (USZ: June 2008 and December 2015). All patients underwent a routine staging procedure consisting of physical examination, chest $\mathrm{x}$-ray, computed tomography $(\mathrm{CT})$, magnetic resonance imaging (MRI) or positron emission tomographycomputed tomography (PET-CT) scan. Routine laboratory tests consisted of complete blood count and chemistry including renal function.

We included patients ( $\geq 18$ years) if they had squamous cell carcinoma of the head and neck, UICC stage II-IV, either treated with primary definitive RCT or radically resected with high-risk features (R1 resection, extracapsular spread in cervical lymph nodes) and treated with adjuvant RCT. Patients had to have received at least one dose of cisplatin to be included.

\section{Data collection}

Medical charts were reviewed systematically considering demographics and clinical characteristics including age, gender, smoking history, alcohol consumption habits and comorbidities. Stage was assessed based on the American Joint Committee on Cancer (AJCC) TNM version 7 classification. Comprehensive data on radiotherapy and chemotherapy treatment details were collected as well as serial laboratory findings with a focus on hemato- and nephrotoxicity. Clinical assessments were performed at 4,8 and 12 weeks after the end of treatment, then every three months for the first two years and semi-annually thereafter. Radiographic follow-up (CT, MRI or PET-CT) was performed 812 weeks after the end of treatment and then semiannually. Follow-up data for all patients were obtained until June 2016 or five years after treatment initiation.

\section{Chemotherapy}

Cisplatin was given either at a dose of $100 \mathrm{mg} / \mathrm{m}^{2}$ every 3 weeks (day 1, 22, and 43) during RT (University Hospital Basel) to a planned cumulative dose of $300 \mathrm{mg} / \mathrm{m}^{2}$ or at a dose of $40 \mathrm{mg} / \mathrm{m}^{2}$ (University Hospital Zurich) or $50 \mathrm{mg} / \mathrm{m}^{2}$ (Cantonal Hospital Winterthur) weekly for 6 or 7 infusions (days $1,8,15,22,29,36$, and 43 ) to a planned cumulative dose of $240-350 \mathrm{mg} / \mathrm{m}^{2}$.

\section{Radiotherapy}

All patients received computed tomography (CT) based radiotherapy planning and were treated with IMRT techniques including static field IMRT or volumetric arc radiotherapy (VMAT). Definitive IMRT was given to a total dose of 69 to $72 \mathrm{~Gy}$ in 33-36 fractions and adjuvant radiotherapy with 60 to 66 Gy in $30-33$ fractions. In general, the first treatment volume included the primary tumor site and elective nodal areas of the bilateral neck. A second treatment volume encompassed the primary tumor site and affected nodes. These volumes were treated either sequentially or simultaneously (simultaneous integrated boost).

\section{Endpoints}

Progression-free survival (PFS) was defined as the time from diagnosis until tumor relapse/progression or death 
from any cause. Overall survival (OS) was defined as the time from diagnosis until death from any cause. Renal toxicity and ototoxicity as adverse events of special interest (AESI) were assessed during RCT and until the first posttreatment assessment 6 weeks after end of therapy according to the Common Terminology Criteria of Adverse Events (CTCAE) version 4.0 [36]

\section{Statistical analysis}

Our primary objective was to assess the association between the cumulative cisplatin dose achieved and the intended treatment protocol. Secondary objectives included investigation of clinical endpoints such as PFS, OS, total radiation dose and toxicity (ototoxicity and renal toxicity).

We stratified patients according to the treatment applied and used descriptive statistics to compare baseline characteristics and outcomes between these groups. For timeto-event endpoints (PFS and OS), we created Kaplan-Meier plots to visualize the respective effects; the log-rank test was used to test for comparison of survival rates. To investigate the association between the chosen cisplatin regimen (weekly versus 3-weekly; dependent variable) and the chance to reach the cumulative cisplatin dose of $\geq 200 \mathrm{mg} /$ $\mathrm{m}^{2}$ (dependent variable), we used multivariable logistic regression techniques with patient age and gender as potential confounders. We have chosen these two clinical variables to adjust for potential confounding, because we assumed that these baseline factors could influence clinical decision making during treatment and alter the chance to reach the cumulative cisplatin dose $\geq 200 \mathrm{mg} / \mathrm{m}^{2}$. To investigate the prognostic impact of the achieved cumulative cisplatin dose (independent variable) on survival, we used a Cox regression model; to account for possible guarantee time bias, a landmark approach was applied only including patients alive 8 weeks after start of treatment. Beside age and gender, we included tumour localization and smoking history to adjust for their potential impact on prognosis. Finally, we investigated the association of the intendend treatment regimen (weekly versus 3-weekly; independent variable) with PFS and OS adjusted for the same confounders as listed above. This analysis was based on the total cohort of patients. In all multivariable models, patients with missing data were excluded, thus we only conducted completed case analyses. In all analyses a two-sided $p<0.05$ was considered statistically significant. Statistical analysis was performed using the statistical program $\mathrm{R}$ (https:// cran.r-project.org/).

\section{Results}

\section{Patient characteristics}

We included 314 eligible patients with a median age of 60 years. Patients' clinical and demographic characteristics are summarized in Table 1. 127 (40.4\%) patients were treated with cisplatin $100 \mathrm{mg} / \mathrm{m}^{2}$ in a 3-weekly schedule and $187(59.6 \%)$ patients received cisplatin $40-50 \mathrm{mg} / \mathrm{m}^{2}$ weekly. The treatment groups were equally distributed with regard to clinical characteristics such as age, gender, tumor localisation, smoking history or comorbidities, with the exception of a slightly higher rate of patients with advanced stage ( $\geq \mathrm{T} 2$ and $\geq \mathrm{N} 2$ ) SCCHN in the 3-weekly cisplatin group compared to the weekly cohort $(64.2 \%$ vs. 51.1\%). This numerical difference did not reach statistical significance.

\section{Treatment characteristics}

127 patients were treated with a 3-weekly regimen. These were all patients treated at the USB $(n=124)$ and 3 patients treated at KSW. 187 patients received a weekly dose of cisplatin. At the USZ, 129 patients were treated with a weekly schedule (125 patients with 40 $\mathrm{mg} / \mathrm{m}^{2}$ weekly and 4 patients with $30 \mathrm{mg} / \mathrm{m}^{2}$ ). Additionally, 17 patients received an induction chemotherapy before the cisplatin-based RCT, predominantly with taxanes, 5-fluorouacil and platinum. At the KSW 58 patients were treated with a weekly schedule $\left(50 \mathrm{mg} / \mathrm{m}^{2}\right.$ in 58 patients and $40 \mathrm{mg} / \mathrm{m}^{2}$ in one patient) and $3 \mathrm{pa}-$ tients received a 3 -weekly schedule.

\section{Treatment regimen and cumulative cisplatin dose}

More patients were able to receive a higher cumulative dose of at least $200 \mathrm{mg} / \mathrm{m}^{2}$ if given at a 3-weekly dose compared with those receiving weekly cisplatin $(N=96$ $(75.6 \%)$ vs. $N=88(47.1 \%, p<0.001)$ (Fig. 1 and Table 2$)$. Median cumulative cisplatin dose was $200 \mathrm{mg} / \mathrm{m}^{2}$ (IQR 150-300) for patients treated with a 3-weekly schedule and $160 \mathrm{mg} / \mathrm{m}^{2}(120-240)$ for the weekly schedule $(p<0.001)$. With regard to chemotherapy compliance, 47 patients $(37 \%)$ of patients treated with a 3-weekly regimen completed the full 3 cycles of treatment and 46 patients (36\%) received 2 cycles. 33 patients $(25.9 \%)$ were changed to a different chemotherapy regimen, most of them to carboplatin (31 patients, 24.4\%). Of patients who received weekly chemotherapy the number of patients who managed to complete six, five, four and three cycles was 22 (11.7\%), 42 (22.4\%), 65 (34.7\%) and 19 (10.1\%), respectively. In the weekly treatment cohort, 37 patients (18.7\%) had to change to a different chemotherapy due to ineligibility for cisplatin in the course of the treatment. 32 patients (17.1\%) switched to cetuximab and 3 patients (1.6\%) to carboplatin. Dose reductions due to adverse events were necessary in $6 / 127$ patients (4.7\%) receiving cisplatin 3 -weekly and $11 / 187$ patients (5.8\%) with a weekly schedule.

In the multivariable logistic regression analysis, patients receiving the the 3-weekly treatment regimen were much more likely to reach the cumulative cisplatin dose of $\geq 200$ 
Table 1 Patient characteristics

\begin{tabular}{|c|c|c|c|c|}
\hline Baseline characteristic & $\begin{array}{l}\text { 3-weekly } \\
(n=127)\end{array}$ & $\begin{array}{l}\text { Weekly } \\
(n=187)\end{array}$ & $\begin{array}{l}\text { Total } \\
(n=314)\end{array}$ & $p$-value \\
\hline Centre & & & & $<0,0011$ \\
\hline - USB & $124(97,6 \%)$ & $0(0 \%)$ & $124(39,5 \%)$ & \\
\hline - KSW & $3(2,4 \%)$ & $58(32 \%)$ & $61(19,4 \%)$ & \\
\hline - USZ & $0(0 \%)$ & $129(69 \%)$ & $129(41,1 \%)$ & \\
\hline Age at diagnosis, mean (SD) & $60.4(8.1)$ & $59.9(8.7)$ & $60.1(8.5)$ & 0.5582 \\
\hline Gender & & & & 0.2731 \\
\hline - Male & $102(80.3 \%)$ & $139(74.3 \%)$ & $241(76.8 \%)$ & \\
\hline - Female & $25(19.7 \%)$ & $48(25.7 \%)$ & $73(23.2 \%)$ & \\
\hline Tumor localisation & & & & 0.1561 \\
\hline - Oropharynx & $57(45.2 \%)$ & $102(54.8 \%)$ & 159 (51\%) & \\
\hline - Oral cavity & $30(23.8 \%)$ & $27(14.5 \%)$ & $57(18.3 \%)$ & \\
\hline - Hypopharynx & $21(16.7 \%)$ & $27(14.5 \%)$ & $48(15.4 \%)$ & \\
\hline - Larynx & $10(7.9 \%)$ & $21(11.3 \%)$ & 31 (9.9\%) & \\
\hline - CUP & $5(4.0 \%)$ & $8(4.3 \%)$ & $13(4.2 \%)$ & \\
\hline - Nasopharynx & $3(2.4 \%)$ & $1(0.5 \%)$ & $4(1.3 \%)$ & \\
\hline Smoking History & & & & 0.0871 \\
\hline - Smoker & 105 (92.9\%) & 155(85.6\%) & $260(88.4 \%)$ & \\
\hline - Non smoker & $8(7.1 \%)$ & $26(14.4 \%)$ & $34(11.6 \%)$ & \\
\hline HPV Status & & & & 0.0931 \\
\hline -Positive & $21(16.5 \%)$ & $34(18.2 \%)$ & $55(17.5 \%)$ & \\
\hline - Negative & $32(25.2 \%)$ & $29(15.5 \%)$ & $61(19.4 \%)$ & \\
\hline - Unknown & $74(58.3 \%)$ & $124(66.3 \%)$ & $198(63.1 \%)$ & \\
\hline T Stage & & & & 0.0811 \\
\hline - TO & 0 & $1(0.6 \%)$ & $1(0.3 \%)$ & \\
\hline$-\mathrm{T} 1$ & $14(11.7 \%)$ & $29(16.2 \%)$ & $43(14.4 \%)$ & \\
\hline$-\mathrm{T} 2$ & 36 (30.0\%) & $74(41.3 \%)$ & $110(36.8 \%)$ & \\
\hline$-\mathrm{T3}$ & 31 (25.8\%) & 35 (19.6\%) & 66 (22.1\%) & \\
\hline - $\mathrm{T} 4$ & $39(32.5 \%)$ & $40(22.3 \%)$ & 79 (26.4\%) & \\
\hline N Stage & & & & 0.6271 \\
\hline - NO & 24 (19.0\%) & $43(23.0 \%)$ & 67 (21.4\%) & \\
\hline$-N 1$ & $13(10.3 \%)$ & 25 (13.4\%) & 38 (12.1\%) & \\
\hline$-\mathrm{N} 2$ & 83 (65.9\%) & 112 (59.9\%) & 195 (62.3\%) & \\
\hline$-N 3$ & $6(4.8 \%)$ & 7 (3.7\%) & $13(4.2 \%)$ & \\
\hline M Stage & & & & 0,4823 \\
\hline - MO & 115 (90.5\%) & 160 (85.5\%) & 275 (87.5\%) & \\
\hline$-M 1$ & 5 (3.9\%) & $3(1.6 \%)$ & $8(2.5 \%)$ & \\
\hline $\begin{array}{l}\text { Advanced Disease } \\
(>=\mathrm{T} 2 \&>=\mathrm{N} 2)\end{array}$ & & & & 0,0341 \\
\hline - Yes & $77(64,2 \%)$ & 99 (51.1\%) & 169 (56.3\%) & \\
\hline - No & $43(35,8 \%)$ & $88(48,9 \%)$ & $131(43,7 \%)$ & \\
\hline Type of CRT & & & & 0.1471 \\
\hline - Definitive & 78 (61.4\%) & $126(67.3 \%)$ & 204 (64.9\%) & \\
\hline - Adjuvant & 49 (38.6\%) & 61 (32.7\%) & 110 (35.1\%) & \\
\hline
\end{tabular}

SD Standard deviation, ${ }^{1}$ Chi-Square test; ${ }^{2}$ t-test; ${ }^{3}$ Fisher's exact test 


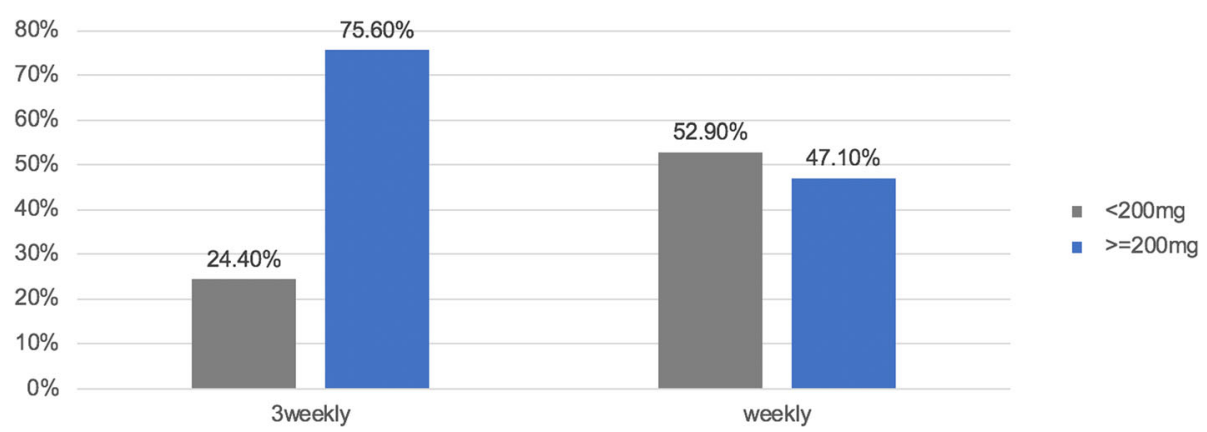

Fig. 1 Cumulative cisplatin dose with a cut-off dose of $200 \mathrm{mg} / \mathrm{m}^{2}$ comparing 3-weekly vs. weekly schedule

$\mathrm{mg} / \mathrm{m}^{2}$ (odds ratio (OR) 3.46, 95\%CI 2.10-5.69), irrespective of age and gender (Table 3 ).

\section{Outcome, progression free survival and overall survival}

Median follow-up time was 40.6 months (range, 1-134 months). At the time of analysis, 120 patients (61.8\%) had a disease progression or a relapse and 198 patients were still alive. Median OS for the whole cohort was 83.8 months (95\%CI 76.6-91.1). In our landmark analysis, we could not confirm that a cisplatin dose $\geq 200$ $\mathrm{mg} / \mathrm{m}^{2}$ is associated with better PFS (HR 0.9, 95\% CI $0.7-1.3$ ) (Fig. 2, Table 4) or OS (HR 1.3, 95\% CI 0.81.9) (Fig. 3, Table 5). There was some evidence that current/former smokers and older patients had a poorer outcome (Table 4); a similar pattern was seen for OS (Table 5). Considering the whole cohort, there was no evidence of a difference between the intended treatment regimens (weekly versus 3-weekly) and PFS (Table 6) or OS (Table 7).

\section{Adverse events and toxicity}

The comparison of both cisplatin regimens revealed that the 3-weekly schedule of cisplatin was associated with significantly higher rate of renal toxicity $(33.1 \%$ vs. $20.9 \%, p=0.016$ ) (Table 4 ). The rate of ototoxicity was similar in both groups $(15 \%$ vs. $12.8 \%, p=0.60)$. Assisted feeding in the form of a feeding tube was used in 81 patients $(63.7 \%)$ in the 3-weekly regime and 105 patients $(56.1 \%)$ in the weekly regimen. In the multivariable regression model, patients receiving the

Table 2 Cisplatin Dose Intensity

\begin{tabular}{|c|c|c|c|}
\hline & $\begin{array}{l}\text { 3-weekly } \\
\text { Cisplatin }\end{array}$ & $\begin{array}{l}\text { Weekly } \\
\text { Cisplatin }\end{array}$ & $\begin{array}{l}p^{-} \\
\text {value }\end{array}$ \\
\hline $\begin{array}{l}\text { Median cumulative cisplatin } \\
\text { dose }\end{array}$ & $200 \mathrm{mg} / \mathrm{m}^{2}$ & $160 \mathrm{mg} / \mathrm{m}^{2}$ & $<0.001$ \\
\hline Cumulative dose $\geq 200 \mathrm{mg}^{2}$ & $96(75.6 \%)$ & $88(47.1 \%)$ & $<0.001$ \\
\hline Dose reduction & $6(4.7 \%)$ & $11(5.8 \%)$ & \\
\hline $\begin{array}{l}\text { Change to other } \\
\text { chemotherapy }\end{array}$ & $33(25.9 \%)$ & $35(18.7 \%)$ & \\
\hline
\end{tabular}

3-weekly treatment regimen were at higher risk for nephrotoxicity (OR 1.88, 95\% CI 1.12-3.16, p = 0.016) and this also increased with age (OR 1.03, 95\%CI $1.00-1.07, p=0.028$ ). None of these factors were associated with ototoxicity (Table 8 ).

\section{Discussion}

This is one of the largest retrospective studies evaluating different treatment regimens for combined radio-chemotherapy in SCCHN patients undergoing combined RCT with cisplatin. We analysed SCCHN patients treated at three different sites in Switzerland. One advantage of this study was, that treatment allocation was done by site (based on internal guidelines) and not on patient-based criteria, thus excluding an important selection bias. Patients treated according to the 3 weekly cisplatin schedule were more likely to achieve a cumulative cisplatin dose of $\geq 200 \mathrm{mg} / \mathrm{m}^{2}$. However, neither the treatment regimen (three weekly versus once weekly) nor the cumulative cisplatin dose of $\geq 200 \mathrm{mg} / \mathrm{m}^{2}$ was associated with improved PFS or OS. However, the weekly regimen was associated with less renal toxicity.

Most randomized trials investigating the role of concurrent cisplatin-based RCT used a three weekly schedule of cisplatin $100 \mathrm{mg} / \mathrm{m}^{2}$ and this treatment regimen is considered the standard therapy in LASCCHN patients. However, it is associated with substantial toxicity and many trials showed suboptimal compliance with cisplatin $100 \mathrm{mg} / \mathrm{m}^{2}$ potentially negatively influencing the outcome [5, 17, 37]. Therefore, low-dose weekly cisplatin schedules are frequently used in clinical practice despite the lack of evidence from prospective randomized trials $[19,21,24,26-28$, $38,39]$.

In a pooled analysis from two tertiary academic cancer centres 659 patients with stage III/IV SCCHN treated with single-agent cisplatin RCT were analysed and a survival benefit for patients receiving a cisplatin dose $>200$ $\mathrm{mg} / \mathrm{m}^{2}$ was shown in HPV negative LA-SCCHN [40]. 
Table 3 Multivariable logisitic regression analysis for Cumulative Cisplatin Dose

\begin{tabular}{llll}
\hline Factor & Odds ratio & $95 \%$ Confidence interval & $p$-value \\
\hline Treatment regimen & 3.46 & $2.10-5.69$ & $<0.0001$ \\
Gender & 1.22 & $0.70-2.13$ & 0.465 \\
Age & 0.99 & $0.96-1.02$ & 0.696 \\
\hline
\end{tabular}

Therefore, a cumulative cisplatin dose of $>200 \mathrm{mg} / \mathrm{m}^{2}$ is usually pursued in this setting.

In our study, treatment compliance was lower with the weekly regimen as reflected by a significantly lower cumulative cisplatin dose. With a weekly regimen less than half of patients achieved a cumulative dose of $>200 \mathrm{mg} / \mathrm{m}^{2}$ whereas this was the case for three-fourths of patients treated with a 3-weekly regimen. We hypothesize that the flexibility to decide on treatment continuation on a weekly basis might lead to more frequent treatment discontinuation even with low-grade toxicities whereas with a three weekly schedule this decision can only be taken at two time points and many patients might have recovered from chemotherapy associated side effects after three weeks. The retrospective analysis by Geiger et al. was limited to stage III/IV SCCHN patients who had surgery and were treated with adjuvant RCT and compared a conventional three weekly regimen $\left(100 \mathrm{mg} / \mathrm{m}^{2}\right)$ to weekly cisplatin with a dose of $25-30 \mathrm{mg} / \mathrm{m}^{2}$ [31]. Of 104 patients, 51 received a three weekly regimen. Similar to our study, the median cisplatin dose was higher with the three weekly regimen. In the retrospective comparison by Rades et al. the proportion of patients achieving a cumulative cisplatin dose of $>200 \mathrm{mg} / \mathrm{m}^{2}$ was not different for the two RCT groups [27]. This study was limited to patients undergoing definitive RCT and did not allow for adjuvant RCT therefore representing a more homogenous patient population. Overall, compared to our study much fewer patients reached the threshold of $200 \mathrm{mg} / \mathrm{m}^{2}$ with 32 and $41 \%$ of patients in the weekly and three weekly group, respectively. The lower cumulative cisplatin dose in the weekly cisplatin group may partially be explained by the weekly dose of $30 \mathrm{mg} / \mathrm{m}^{2}$ used in a part of patients. The authors did not provide exact numbers for patients receiving 30 $\mathrm{mg} / \mathrm{m}^{2}$ or $40 \mathrm{mg} / \mathrm{m}^{2}$ weekly, respectively. In our study, two third of patients were treated with a weekly dose of $40 \mathrm{mg} / \mathrm{m}^{2}$ and $30 \%$ of patients even received a weekly dose of $50 \mathrm{mg} / \mathrm{m}^{2}$. Also the randomized trial by Noronha used a weekly cisplatin dose of $30 \mathrm{mg} / \mathrm{m}^{2}$ [23]. This dose is frequently used in clinical practice based on retrospective data $[38,41,42]$ and two randomized trials from the Indian group [43, 44]. Our study provides additional evidence that the $200 \mathrm{mg} / \mathrm{m}^{2}$ cumulative dose can be reached more often by using a three weekly regimen of cisplatin. The more important question of course is, whether this threshold is a valid surrogate marker for PFS or OS.

We did not find an impact of the treatment regimen on the outcome. A recent systematic review compared 4 prospective studies with weekly cisplatin regimen to 7 prospective studies using a 3-weekly high-dose cisplatin treatment and reported superior outcome for the highdose cisplatin treatment [18]. A small randomized study

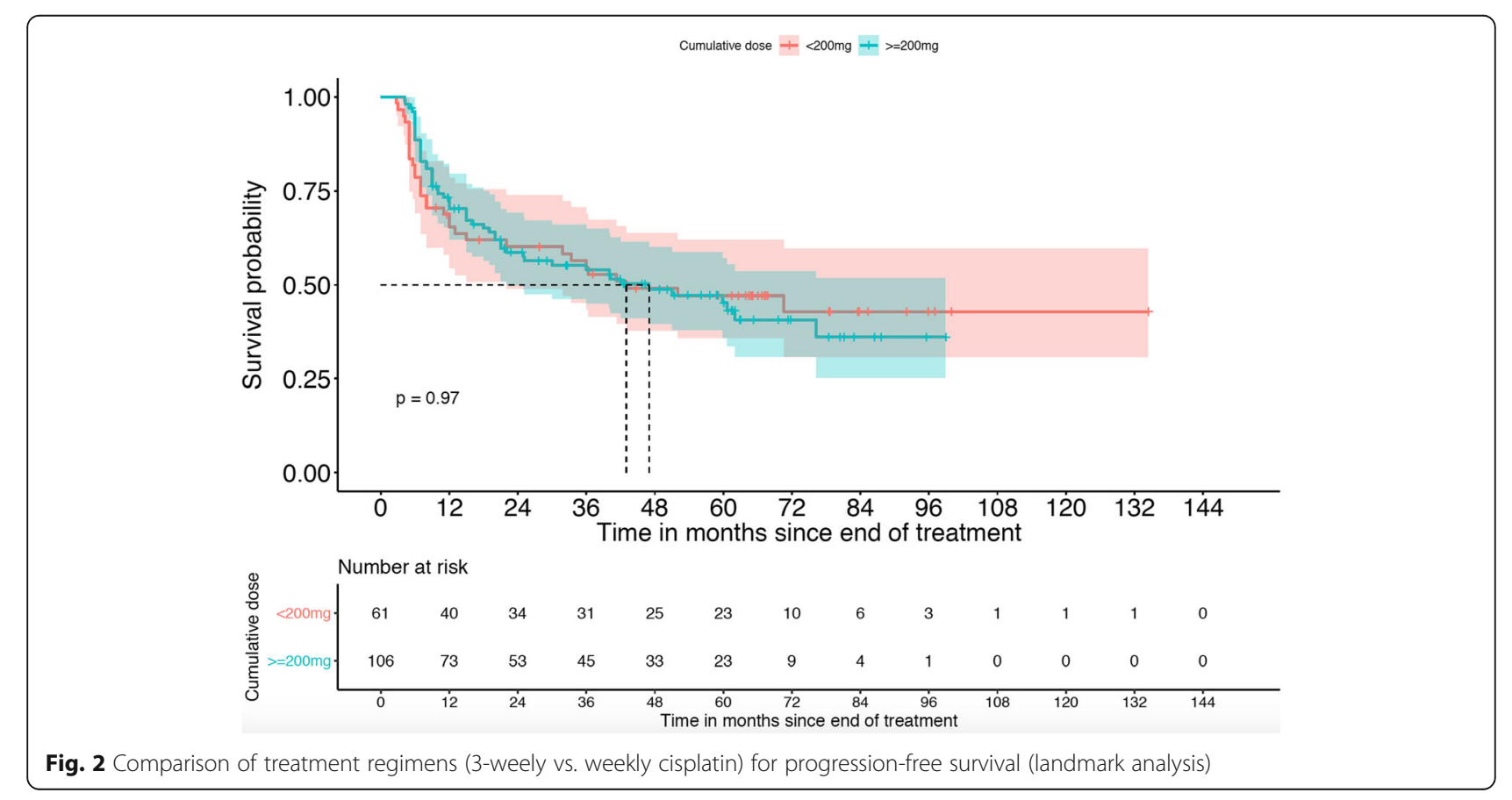


Table 4 Multivariable Cox regression analysis for PFS including cumulative cisplatin dose; landmark analysis only including patients alive 8 weeks after end of treatment

\begin{tabular}{llll}
\hline Factor & $\begin{array}{l}\text { Hazard } \\
\text { Ratio }\end{array}$ & $\begin{array}{l}\text { 95\% Confidence } \\
\text { interval }\end{array}$ & p-value \\
\hline $\begin{array}{l}\text { Cumulative cisplatin } \\
\text { dose }\end{array}$ & 0.92 & $0.65-1.29$ & 0.641 \\
Gender & 1.10 & $0.74-1.65$ & 0.617 \\
Age at diagnosis & 1.01 & $0.99-1.03$ & 0.089 \\
$\begin{array}{l}\text { Hypopharyngeal } \\
\text { localisation }\end{array}$ & 0.88 & $0.56-1.37$ & 0.582 \\
Smoking history & 2.25 & $1.13-4.47$ & 0.02 \\
\hline
\end{tabular}

compared $100 \mathrm{mg} / \mathrm{m}^{2}$ cisplatin every 3 weeks to weekly $40 \mathrm{mg} / \mathrm{m}^{2}$ [34]. This trial was limited to patients with oral cavity tumors and did not show differences in locoregional control and survival. In addition, with only 50 patients enrolled, this small trial was underpowered to show potential differences. Recently, a large randomized non-inferiority trial $(N=300)$ compared cisplatin $30 \mathrm{mg} / \mathrm{m}^{2}$ given once a week and cisplatin $100 \mathrm{mg} / \mathrm{m}^{2}$ given once every 3 weeks concurrently with curative intent RT was published [23]. The primary aim to show non-inferiority for the weekly regimen was not reached. In fact, locoregional tumor control was superior with the high-dose 3-weekly regimen. Most patients (93\%) included in the trial had tumor resection before and RCT was given as adjuvant therapy. Moreover, the trial population consisted mainly of oral cavity tumors $(87.3 \%)$ in patients with smokeless tobacco consumption (71.3\%). Only $19.7 \%$ of patients were smokers. In our study, oral cavity cancers only account for $18.3 \%$ of all tumors and $88.4 \%$ of patients were smokers. It is therefore questionable if the results of the randomized trial from a large academic hospital in India are applicable for Western patient populations with a predominance of smoking-associated pharyngeal carcinomas.

Retrospective studies comparing weekly and three weekly RCT regimens demonstrated conflicting results. The trial by Espeli et al. with 94 patients demonstrated improved OS and similar PFS with cisplatin $100 \mathrm{mg} / \mathrm{m}^{2}$ every 3 week compared to $40 \mathrm{mg} / \mathrm{m}^{2}$ weekly [30]. Importantly, patients in the weekly cisplatin group were significantly older introducing a potential bias for outcome and toxicities. As in our study cumulative cisplatin dose was significantly lower with the weekly regimen. Significantly more patients in the high-dose cisplatin group developed chronic renal failure whereas in our trial differences in renal toxicity was limited to the acute phase. The retrospective comparison by Rades et al. also showed better locoregional control and OS when using cisplatin $100 \mathrm{mg} / \mathrm{m}^{2}$ every three weeks compared to $30-40 \mathrm{mg} / \mathrm{m}^{2}$ weekly in 133 patients with LA-SCCHN [27]. In the previously discussed study by Geiger et al. there was no difference in loco-regional control but a trend towards a better survival with 3weekly cisplatin [31].

In our study, $65 \%$ of patients were treated with curative intent definitive RCT, the others received RCT in the adjuvant setting. The heterogeneity of treatment regimens may have confounded our results although the distribution between definitive and adjuvant RCT was similar in the high- and low-dose cisplatin groups in our study. Another limitation of our study is that HPV status was only available in 116 patients (36.9\%). Proportions of HPV positive patients were similar in both RCT groups but

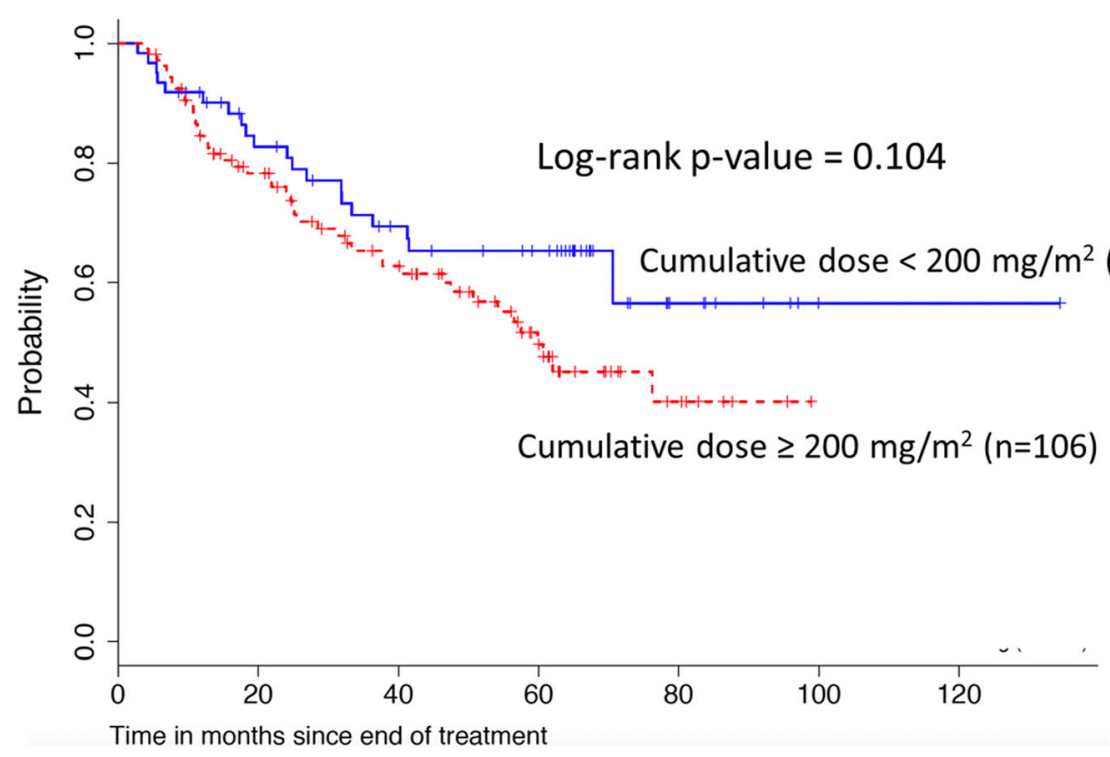

Fig. 3 Comparison of treatment regimens (3-weely vs. weekly cisplatin) for overall survival (landmark analysis) 
Table 5 Multivariable Cox regression analysis for OS including cumulative cisplatin dose; landmark analysis only including patients alive 8 weeks after end of treatment

\begin{tabular}{llll}
\hline Factor & $\begin{array}{l}\text { Hazard } \\
\text { ratio }\end{array}$ & $\begin{array}{l}\text { 95\% Confidence } \\
\text { interval }\end{array}$ & $p$-value \\
\hline $\begin{array}{l}\text { Cumulative cisplatin } \\
\text { dose }\end{array}$ & 1.25 & $0.84-1.87$ & 0.263 \\
Gender & 1.05 & $0.66-1.67$ & 0.821 \\
Age at diagnosis & 1.02 & $1.00-1.05$ & 0.012 \\
$\begin{array}{l}\text { Hypopharyngeal } \\
\text { localisation }\end{array}$ & 1.09 & $0.66-1.80$ & 0.735 \\
Smoking history & 1.98 & $0.91-4.31$ & 0.082 \\
\hline
\end{tabular}

heterogeneity based on missing HPV analysis in the majority of patients cannot be excluded. The study by Spreafico et al. showed an impact of a cumulative cisplatin dose $>200 \mathrm{mg} / \mathrm{m}^{2}$ in patients with HPV negative LA-SCCHN therefore suggesting different sensibility to cisplatin in general or the dose intensity of cisplatin. In the previously discussed analysis by Geiger et al. 50\% of patients had HPV-associated oropharyngeal cancer [31]. Although there was a trend towards a better survival for patients treated with a 3-weekly regimen, this difference was not seen in the subgroup of HPV positive patients suggesting that a less intense treatment regimen might be sufficient for patients with HPV-associated LA-SCCHN.

In our study, we found significantly higher renal toxicity with a 3-weekly cisplatin regimen. Interestingly, results from previously discussed studies report conflicting results with regard to toxicity. Several studies reported higher toxicity for 3-weekly cisplatin, mainly renal toxicity [26-28, 30], but also hematotoxicity [27] and mucositis/dermatitis [28]. In contrast, Tsan et al. reported a higher rate of mucositis and overall toxicity in the weekly cisplatin group [34]. Also the recent comparative analysis of different prospective trials showed less toxicities with the 3-weekly regimen [18]. The fact that this is a retrospective study limits the value of toxicity assessment as we were not able to perform a comprehensive adverse event and toxicity assessment. We therefore decided to investigate oto- and nephrotoxicity

Table 6 Multivariable Cox regression analysis for PFS; whole cohort

\begin{tabular}{llll}
\hline Factor & $\begin{array}{l}\text { Hazard } \\
\text { ratio }\end{array}$ & $\begin{array}{l}95 \% \text { Confidence } \\
\text { interval }\end{array}$ & $\begin{array}{l}p \text { - } \\
\text { value }\end{array}$ \\
\hline $\begin{array}{l}\text { Treatment regimen (weekly vs. } \\
\text { 3-weekly) }\end{array}$ & 0.89 & $0.62-1.26$ & 0.515 \\
Gender & 1.11 & $0.74-1.66$ & 0.744 \\
Age at diagnosis & 1.01 & $0.99-1.03$ & 0.071 \\
Hypopharyngeal localisation & 0.88 & $0.57-1.38$ & 0.603 \\
Smoking history & 2.29 & $1.15-4.53$ & 0.017 \\
\hline
\end{tabular}

Table 7 Multivariable Cox regression analysis for OS; whole cohort

\begin{tabular}{llll}
\hline Factor & $\begin{array}{l}\text { Hazard } \\
\text { Ratio }\end{array}$ & $\begin{array}{l}\text { 95\% Confidence } \\
\text { interval }\end{array}$ & $p$-value \\
\hline $\begin{array}{l}\text { Treatment regimen } \\
\text { (weekly vs. 3-weekly) }\end{array}$ & 1.37 & $0.92-2.03$ & 0.116 \\
Gender & 1.08 & $0.68-1.71$ & 0.741 \\
Age at diagnosis & 1.02 & $1.00-1.05$ & 0.017 \\
$\begin{array}{l}\text { Hypopharyngeal } \\
\text { localisation }\end{array}$ & 1.03 & $0.62-1.70$ & 0.893 \\
Smoking history & 2.00 & $0.92-4.33$ & 0.078 \\
\hline
\end{tabular}

as two of the main long-term toxicities in patients treated with cisplatin.

Existing results comparing three weekly and weekly cisplatin regimen combined with RT are conflicting and because they are retrospective they always bear the risk of selection bias. The only statistically powered prospective randomized trial did not prove non-inferiority for a weekly regimen [23]. However, based on the previously discussed issues the validity of the trial for LA-SCCHN in Western countries is questionable. Our study shows a significant higher cumulative cisplatin dose with a 3weekly regimen. However, we couldn't find differences in survival outcomes challenging recent data suggesting the prognostic impact of a cumulative cisplatin dose higher than $200 \mathrm{mg} / \mathrm{m}^{2}$ [40]. The retrospective design of this large study with all its inherent problems and potential biases makes it difficult to draw definitive conclusions from the analysis. We made every attempt to assess the biases by using multivariable analyses. However, further prospectively randomized trials are needed to establish the most effective RCT treatment regimen. Currently, a randomized phase 3 trial comparing cisplatin $40 \mathrm{mg} / \mathrm{m}^{2}$ weekly with $100 \mathrm{mg} / \mathrm{m}^{2}$ every three weeks combined with RT is ongoing [45].

\section{Conclusions}

This retrospective, multicentre study with more than 300 patients demonstrates that significantly more patients receive a cumulative of dose of $\geq 200 \mathrm{mg} / \mathrm{m}^{2}$, when

Table 8 Cisplatin treatment regimen and acute toxicity

\begin{tabular}{cclll}
\hline Toxicity & $\begin{array}{l}\text { 3-weekly } \\
(n=127)\end{array}$ & $\begin{array}{l}\text { Weekly } \\
(n=187)\end{array}$ & $\begin{array}{l}\text { Total } \\
(n=314)\end{array}$ & $p$-value \\
\hline \multicolumn{2}{l}{ Nephrotoxicity } & & & 0.016 \\
Yes & $42(33.1 \%)$ & $39(20.9 \%)$ & $81(25.8 \%)$ & \\
No & $85(66.9 \%)$ & $148(79.1 \%)$ & $233(74.2 \%)$ & \\
Ototoxicity & & & & 0.711 \\
Yes & $19(15 \%)$ & $24(12.8 \%)$ & $43(13.7 \%)$ & \\
No & $108(85 \%)$ & $163(87.2 \%)$ & $271(86.3 \%)$ & \\
\hline
\end{tabular}


treated with a 3-weekly schedule compared to weekly dosing. However, we could not find differences in survival between the regimens. Furthermore, we could not confirm previous data suggesting that a cumulative cisplatin dose $\geq 200 \mathrm{mg} / \mathrm{m}^{2}$ is associated with better survival. The 3weekly regimen led to a higher rate of renal toxicity. Although a 3-weekly regimen allows for a higher cumulative cisplatin dose, weekly cisplatin may be an acceptable alternative treatment considering toxicity. Well-designed prospective trials are needed to establish the most effective RCT treatment regimen and to define patient subgroups that need more intense treatment regimens.

\section{Abbreviations}

AE: Adverse event; Cl: Confidence interval; CT: Computertomography; HPV: Human papilloma virus; HR: Hazard ratio; IMRT: Intensity modulated radiotherapy; IQR: Interquartile range; KSW: Kantonsspital Winterthur (Cantonal Hospital Winterthur); LA-SCCHN: Locally advanced squamous cell carcinoma of the head and neck; OR: Odds ratio; OS: Overall survival; PET: Positron emission tomography; PFS: Progression-free survival; Pts: Patients; RCT: Radio-chemotherapy; RT: Radiotherapy; SCCHN: Squamous cell carcinoma of the head and neck; USB: University Hospital Basel; USZ: University Hospital Zürich

\section{Acknowledgements}

Not applicable.

\section{Funding}

This project is financially supported by institutional funds of the involved oncology departments at Universitätsspital Basel, Universitätsspital Zürich und Kantonsspital Winterthur.

\section{Availability of data and materials}

All data generated or analysed during this study are included in this published article.

\section{Authors' contributions}

Conception and study design: MP, SIR. Development of methodology: SH, MP, SIR. Acquisition of data: SH, OR, URM, AP, MP, SIR. Analysis and interpretation of data: SH, BK, MP, SIR. Writing and review of the manuscript: SH, OR, URM, AP, BK, MP, SIR. Study supervision: MP, SIR. All authors read and approved the final manuscript.

\section{Ethics approval and consent to participate}

This study was performed in accordance with institutional review board approval by the local ethical committees (ethical committee of northwestern and central part of Switzerland, (EKNZ) and cantonal ethical committee Zurich (KEK), approval number 2016-01062).

\section{Consent for publication}

Not applicable.

\section{Competing interests}

The authors declare that they have no competing interests.

\section{Publisher's Note}

Springer Nature remains neutral with regard to jurisdictional claims in published maps and institutional affiliations.

\section{Author details}

${ }^{1}$ Department Internal Medicine, University Hospital Basel, Medical Oncology, Petersgraben 4, 4031 Basel, Switzerland. ${ }^{2}$ Clinic for Radiation Oncology, University Hospital and University of Zürich, Rämistrasse 100, 8091 Zürich, Switzerland. ${ }^{3}$ Cantonal Hospital Winterthur, Clinic for Radiation Oncology, Brauerstrasse 15, 8400 Winterthur, Switzerland. ${ }^{4}$ Clinic for Radiotherapy and Radio-Oncology, University Hospital Basel, Petersgraben 4, 4031 Basel,
Switzerland. ${ }^{5}$ Medical Oncology, Cantonal Hospital Winterthur, Brauerstrasse 15, 8400 Winterthur, Switzerland.

Received: 29 November 2018 Accepted: 4 February 2019

Published online: 11 February 2019

\section{References}

1. Rodriguez CP, Adelstein DJ. Survival trends in head and neck Cancer: opportunities for improving outcomes. Oncologist. 2010;15:921-3.

2. Jakobsen KK, Grønhøj C, Jensen DH, Karnov KKS, Agander TK, Specht L, et al. Increasing incidence and survival of head and neck cancers in Denmark: a nation-wide study from 1980 to 2014. Acta Oncol (Madr). 2018:1-9.

3. Megwalu UC, Sirjani D, Devine EE. Oropharyngeal squamous cell carcinoma incidence and mortality trends in the United States, 1973-2013. Laryngoscope. 2018;128:1582-8.

4. Chaturvedi AK, Engels EA, Pfeiffer RM, Hernandez BY, Xiao W, Kim E, et al. Human papillomavirus and rising oropharyngeal Cancer incidence in the United States. J Clin Oncol. 2011;29:4294-301.

5. Adelstein DJ, Li Y, Adams GL, Wagner H Jr, Kish JA, Ensley JF, et al. An intergroup phase III comparison of standard radiation therapy and two schedules of concurrent chemoradiotherapy in patients with unresectable squamous cell head and neck cancer. J Clin Oncol. 2003;21:92-8.

6. Forastiere AA, Goepfert H, Maor M, Pajak TF, Weber R, Morrison W, et al. Concurrent chemotherapy and radiotherapy for organ preservation in advanced laryngeal cancer. N Engl J Med. 2003;349:2091-8.

7. Huguenin P, Beer KT, Allal A, Rufibach K, Friedli C, Davis JB, et al. Concomitant cisplatin significantly improves locoregional control in advanced head and neck cancers treated with hyperfractionated radiotherapy. J Clin Oncol. 2004;22:4665-73.

8. Cooper JS, Pajak TF, Forastiere AA, Jacobs J, Campbell BH, Saxman SB, et al. Postoperative concurrent radiotherapy and chemotherapy for high-risk squamous-cell carcinoma of the head and neck. N Engl J Med. 2004;350:1937-44.

9. Bernier J, Domenge C, Ozsahin M, Matuszewska K, Lefèbvre J-L, Greiner RH, et al. Postoperative irradiation with or without concomitant chemotherapy for locally advanced head and neck cancer. N Engl J Med. 2004;350:1945-52.

10. Bernier J, Cooper JS, Pajak TF, van Glabbeke M, Bourhis J, Forastiere A, et al. Defining risk levels in locally advanced head and neck cancers: a comparative analysis of concurrent postoperative radiation plus chemotherapy trials of the EORTC (\#22931) and RTOG (\# 9501). Head Neck. 2005;27:843-50

11. Pignon JP, le Maitre A, Maillard E, Bourhis J. Meta-analysis of chemotherapy in head and neck cancer (MACH-NC): an update on 93 randomised trials and 17,346 patients. Radiother Oncol. 2009:92:4-14.

12. Budach W, Hehr T, Budach V, Belka C, Dietz K. A meta-analysis of hyperfractionated and accelerated radiotherapy and combined chemotherapy and radiotherapy regimens in unresected locally advanced squamous cell carcinoma of the head and neck. BMC Cancer. 2006;6:28.

13. Fountzilas G, Skarlos D, Kosmidis P, Samantas E, Kalogera-Fountzila A, Papaspyrou S, et al. Radiation therapy and concurrent cisplatin administration in locally advanced head and neck cancer. A Hellenic co-operative oncology group study. Acta Oncol. 1994;33:825-30.

14. Nguyen-Tan PF, Zhang Q, Ang KK, Weber RS, Rosenthal DI, Soulieres D, et al Randomized phase III trial to test accelerated versus standard fractionation in combination with concurrent cisplatin for head and neck carcinomas in the radiation therapy oncology group 0129 trial: long-term report of efficacy and toxicity. J Clin Oncol. 2014;32:3858-67.

15. O'Sullivan B, Huang SH, Siu LL, Waldron J, Zhao H, Perez-Ordonez B, et al. Deintensification candidate subgroups in human papillomavirus-related oropharyngeal cancer according to minimal risk of distant metastasis. J Clin Oncol. 2013;31:543-50

16. Trotti A, Pajak TF, Gwede CK, Paulus R, Cooper J, Forastiere A, et al. TAME: development of a new method for summarising adverse events of cancer treatment by the radiation therapy oncology group. Lancet Oncol. 2007;8: 613-24.

17. Browman GP, Hodson DI, Mackenzie RJ, Bestic N, Zuraw L. Cancer Care Ontario practice guideline initiative head and neck Cancer disease site group. Choosing a concomitant chemotherapy and radiotherapy regimen for squamous cell head and neck cancer: A systematic review of the published literature with subgroup analysis. Head Neck. 2001;23:579-89.

18. Szturz P, Wouters K, Kiyota N, Tahara M, Prabhash K, Noronha V, et al. Altered fractionation radiotherapy combined with concurrent low-dose or 
high-dose cisplatin in head and neck cancer: a systematic review of literature and meta-analysis. Oral Oncol. 2018;76:52-60.

19. Bachaud JM, Cohen-Jonathan E, Alzieu C, David JM, Serrano E, Daly-Schveitzer N. Combined postoperative radiotherapy and weekly cisplatin infusion for locally advanced head and neck carcinoma: final report of a randomized trial. Int J Radiat Oncol Biol Phys. 1996;36:999-1004.

20. Jeremic B, Shibamoto Y, Stanisavljevic B, Milojevic L, Milicic B, Nikolic N. Radiation therapy alone or with concurrent low-dose daily either cisplatin or carboplatin in locally advanced unresectable squamous cell carcinoma of the head and neck: a prospective randomized trial. Radiother Oncol. 1997; 43:29-37.

21. Rampino M, Ricardi U, Munoz F, Reali A, Barone C, Musu AR, et al. Concomitant adjuvant chemoradiotherapy with weekly low-dose cisplatin for high-risk squamous cell carcinoma of the head and neck: a phase II prospective trial. Clin Oncol (R Coll Radiol). 2011;23:134-40.

22. Sharma A, Mohanti BK, Thakar A, Bahadur S, Bhasker S. Concomitant chemoradiation versus radical radiotherapy in advanced squamous cell carcinoma of oropharynx and nasopharynx using weekly cisplatin: a phase II randomized trial. Ann Oncol Off J Eur Soc Med Oncol. 2010:21:2272-7.

23. Noronha V, Joshi A, Patil VM, Agarwal J, Ghosh-Laskar S, Budrukkar A, et al. Once-a-week versus once-Every-3-weeks cisplatin Chemoradiation for locally advanced head and neck Cancer: a phase III randomized noninferiority trial. J Clin Oncol. 2018;36:1064-72.

24. Homma A, Inamura N, Oridate N, Suzuki S, Hatakeyama H, Mizumachi T, et al. Concomitant weekly cisplatin and radiotherapy for head and neck cancer. Jpn J Clin Oncol. 2011;41:980-6.

25. Strojan P, Vermorken JB, Beitler JJ, Saba NF, Haigentz M, Bossi P, et al. Cumulative cisplatin dose in concurrent chemoradiotherapy for head and neck cancer: a systematic review. Head Neck. 2016;38:E2151-8.

26. Ho KF, Swindell R, Brammer CV. Dose intensity comparison between weekly and 3-weekly cisplatin delivered concurrently with radical radiotherapy for head and neck cancer: a retrospective comparison from new cross hospital, Wolverhampton, UK. Acta Oncol. 2008;47:1513-8.

27. Rades D, Seidl D, Janssen S, Bajrovic A, Karner K, Strojan P, et al. Comparison of weekly administration of cisplatin versus three courses of cisplatin $100 \mathrm{mg} / \mathrm{m} 2$ for definitive radiochemotherapy of locally advanced head-and-neck cancers. BMC Cancer. 2016;16:437.

28. Fayette J, Molin Y, Lavergne E, Montbarbon X, Racadot S, Poupart M, et al. Radiotherapy potentiation with weekly cisplatin compared to standard every 3 weeks cisplatin chemotherapy for locoregionally advanced head and neck squamous cell carcinoma. Drug Des Devel Ther. 2015;9:6203-10.

29. Geeta SN, Padmanabhan TK, Samuel J, Pavithran K, lyer S, Kuriakose MA. Comparison of acute toxicities of two chemotherapy schedules for head and neck cancers. J Cancer Res Ther. 2006;2:100-4.

30. Espeli V, Zucca E, Ghielmini M, Giannini O, Salatino A, Martucci F, et al. Weekly and 3-weekly cisplatin concurrent with intensity-modulated radiotherapy in locally advanced head and neck squamous cell cancer. Oral Oncol. 2012;48:266-71.

31. Geiger JL, Lazim AF, Walsh FJ, Foote RL, Moore EJ, Okuno SH, et al. Adjuvant chemoradiation therapy with high-dose versus weekly cisplatin for resected, locally-advanced HPV/p16-positive and negative head and neck squamous cell carcinoma. Oral Oncol. 2014;50:311-8.

32. Oosting SF, Chen TWW, Huang SH, Wang L, Waldron J, Gilbert R, et al. A comparison of weekly versus 3-weekly cisplatin during adjuvant radiotherapy for high-risk head and neck cancer. Oral Oncol. 2016;59:43-9.

33. Uygun K, Bilici A, Karagol H, Caloglu M, Cicin I, Aksu G, et al. The comparison of weekly and three-weekly cisplatin chemotherapy concurrent with radiotherapy in patients with previously untreated inoperable non-metastatic squamous cell carcinoma of the head and neck. Cancer Chemother Pharmacol. 2009;64:601-5.

34. Tsan D-L, Lin C-Y, Kang C-J, Huang S-F, Fan K-H, Liao C-T, et al. The comparison between weekly and three-weekly cisplatin delivered concurrently with radiotherapy for patients with postoperative high-risk squamous cell carcinoma of the oral cavity. Radiat Oncol. 2012;7:215.

35. Sahoo TK, Samanta DR, Senapati SN, Parida K. A comparative study on weekly versus three weekly Cisplatinum based Chemoradiation in locally advanced head and neck cancers. J Clin DIAGNOSTIC Res. 2017;11:XC07-11.

36. Common Terminology Criteria of Adverse Events (CTCAE) version 4.0. 2009. https://evs.nci.nih.gov/ftp1/CTCAE/CTCAE_4.03/Archive/CTCAE_4.0_2009-0529 QuickReference $8.5 \times 11$.pdf.
37. Pajak TF, Laramore GE, Marcial VA, Fazekas JT, Cooper J, Rubin P, et al. Elapsed treatment days--a critical item for radiotherapy quality control review in head and neck trials: RTOG report. Int J Radiat Oncol Biol Phys. 1991;20:13-20.

38. Gupta T, Agarwal J, Ghosh-Laskar S, Parikh PM, D'Cruz AK, Dinshaw KA. Radical radiotherapy with concurrent weekly cisplatin in loco-regionally advanced squamous cell carcinoma of the head and neck: a single-institution experience. Head Neck Oncol. 2009;1:17.

39. Porceddu SV, Campbell B, Rischin D, Corry J, Weih L, Guerrieri M, et al. Postoperative chemoradiotherapy for high-risk head-and-neck squamous cell carcinoma. Int J Radiat Oncol Biol Phys. 2004;60:365-73.

40. Spreafico A, Huang SH, Xu W, Granata R, Liu C-S, Waldron JN, et al. Impact of cisplatin dose intensity on human papillomavirus-related and -unrelated locally advanced head and neck squamous cell carcinoma. Eur J Cancer. 2016:67:174-82.

41. Traynor AM, Richards GM, Hartig GK, Khuntia D, Cleary JF, Wiederholt PA, et al. Comprehensive IMRT plus weekly cisplatin for advanced head and neck cancer: the University of Wisconsin experience. Head Neck. 2010;32: 599-606.

42. Boulmay BC, Chera BS, Morris CG, Kirwan J, Riggs CE, Lawson M, et al. Definitive altered fractionation radiotherapy and concomitant weekly cisplatin for locally advanced head and neck cancer. Am J Clin Oncol. 2009; 32:488-91.

43. Ghosh Laskar S, Chaukar D, Deshpande M, Chatterjee A, Hawaldar RW, Chakraborty S, et al. Phase III randomized trial of surgery followed by conventional radiotherapy ( $5 \mathrm{fr} / \mathrm{Wk}$ ) (Arm A) vs concurrent chemoradiotherapy (Arm B) vs accelerated radiotherapy (6fr/Wk) (Arm C) in locally advanced, stage III and IV, resectable, squamous cell carcinoma o. J Clin Oncol. 2016;34(suppl):abstr 6004

44. Ghosh-Laskar S, Kalyani N, Gupta T, Budrukkar A, Murthy V, Sengar M, et al. Conventional radiotherapy versus concurrent chemoradiotherapy versus accelerated radiotherapy in locoregionally advanced carcinoma of head and neck: results of a prospective randomized trial. Head Neck. 2016;38:202-7.

45. Kunieda F, Kiyota N, Tahara M, Kodaira T, Hayashi R, Ishikura S, et al. Randomized phase I/III trial of post-operative chemoradiotherapy comparing 3-weekly cisplatin with weekly cisplatin in high-risk patients with squamous cell carcinoma of head and neck: Japan clinical oncology group study (JCOG1008). Jpn J Clin Oncol. 2014;44:770-4.

\section{Ready to submit your research? Choose BMC and benefit from:}

- fast, convenient online submission

- thorough peer review by experienced researchers in your field

- rapid publication on acceptance

- support for research data, including large and complex data types

- gold Open Access which fosters wider collaboration and increased citations

- maximum visibility for your research: over $100 \mathrm{M}$ website views per year

At BMC, research is always in progress.

Learn more biomedcentral.com/submissions 